\title{
Efficiency of large firms operating in the Croatian food industry: Data envelopment analysis
}

\author{
MAJA PERVAN \\ Department of Economics \\ University of Split, Faculty of Economics, Business and Tourism \\ Cvite Fiskovića 5, 21000 Split \\ CROATIA
}

\begin{abstract}
The aim of this research was to estimate the overall technical, pure technical and scale efficiency of large firms operating in the Croatian food industry. The analysis was conducted using Data Envelopment Analysis, while applying both, CCR and BCC output-oriented model. With this approach, it was possible to identify efficient firms that can serve as examples of the best operating practice, as well as those inefficient firms which need to improve their performance. The obtained results revealed a high level of achieved overall technical, pure technical and scale efficiency, as well as the fact that firms in this industry mainly over-utilize the existing scale size.
\end{abstract}

Key-Words: - Croatia, efficiency, DEA, large firms, food industry

Received: October 07, 2019. Revised: May 2, 2020. Accepted: May 9, 2020. Published: May 20, 2020.

\section{Introduction}

Manufacturing sector, within which food industry is positioned, plays the most important role not only in the Croatian economy but in many other economies as well. The growth of manufacturing sector and technological improvements in it, are usually seen as main drivers of economic growth. Aside from being key to prosperity and core sector to develop national wealth and power, manufacturing industry is also foundation for job creation. For example, in 2018 , the Croatian manufacturing sector accounted for $25.6 \%$ of all employees, while generating $23.8 \%$ of total revenue and $21.1 \%$ of profits at the national level [1].

Significance of food industry, as the most prominent part of manufacturing sector, can be further corroborated in terms of absolute numbers, according to which it generated $€ 4,8$ million of revenue in 2018 [1] and forecast is that it will (together with beverage industry) create around $€ 9,8$ million of revenue in 2020 in Croatia [2]. The importance of this industry, beyond national level, can be supported by 4,72 million of employees, $€ 1.2$ trillion of turnover and $€ 236$ billion in value added at the level of the European Union (EU) [3].

The most powerful economies are those with strong manufacturing sector and prosperous firms operating within. However, it is not enough to have factories and employees that produce goods e.g. food, a firm has to be efficient and produce as much as possible outputs from a given level of inputs. Many different (efficiency) ratios are often calculated to capture various aspects of firm's performance, but these multiple ratios can produce mixed results that might confuse managers in rating his/her firm among comparable units. Thus, in order to obtain a single efficiency score from a multiple inputs and outputs, in this research a data envelopment analysis (DEA) is applied. DEA is a non-parametric technique, based on linear programming, aimed to determine relative efficiency of decision making units (DMU), represented in this study by very large and large (hereafter: large) firms operating in the Croatian food industry.

To the best of author's knowledge, this is the first study in which the overall technical efficiency, scale efficiency and returns to scale is estimated for the Croatian food industry.

The paper is organized as follows. The second section provides literature review. Methodology and the selection of inputs and outputs are discussed in section three, while section four provides the results of the analysis. The last section concludes.

\section{Literature review}

Due to its relevance, a food industry has always attracted the curiosity of numerous researchers who endeavoured to explore it from various aspects and with application of different techniques. Still, a prevalent number of the researchers focused their attention on food firm's performance. While some researchers investigated supply chain capabilities and its relationship to corporate performance [4] and 
proposed sustainability assessment framework which included major performance indices in food supply network [5], the others analyzed different influential performance factors, e.g. the effect of vertical ownership on export performance [6], relationship between innovative performance and open innovation [7], general exploration of financial performance during the time [8], the impact of firm's age on its performance [9], the influence of exports of food products on competitiveness of the food industry [10] and so on, whereas the latter two studies were conducted on the sample of the Croatian food firms.

As regards the application of the Data envelopment analysis in researches in general, and in food industry in particular, the situation is as follows. The most recent literature survey showed a continuous and rapid exponential growth in the number of theoretical and empirical publications related to DEA. The most popular area of DEA methodology application is in banking, industry, energy, healthcare and education [11], [12]. In the last four decades, a little bit less than 10000 DEArelated articles have been published [11]. Although abundance of studies can be found for the previously listed area of research, e.g. [13], [14], [15] and [16] for banking; [17], [18], [19] and [20] for healthcare; [21], [22], [23] and [24] for education; the empirical literature dealing with DEA application in food industry is still relatively scarce. Therefore, a special attention will be devoted to these studies and their brief presentation will be provided in following paragraphs.

A certain number of studies were conducted on a sample of listed firms. For example, while examining the efficiency of 22 listed food companies in Pakistan, the researchers [25] found out that technical efficiency scores had improved during the years, while reaching its peak of 0.9 in 2010. However, the scale efficiency scores (SE) were not so encouraging, since the range of SE varied between 0.5 and 0.7 . On the other hand, aiming to assess the performance of 23 Turkish food and beverage listed firms, the authors [26] used DEA technique and revealed that export increased supply chain efficiency scores for the majority of companies. The results also demonstrated that the Turkish companies could not utilize their resources effectively to create sufficient profits.

The study of [27] evaluated the efficiency of 10 listed companies operating in food and beverage industry in Taiwan during the 2011-2014 period. With the application of Mann-Whitney $U$ test, the authors revealed that the dessert and beverage companies were more efficient than the food companies, as the p-value among the analysed group (food vs. beverage) found to be significant $(p<0,025)$ for each of the analysed years. Additional research conducted in Taiwan was that of [28] in which returns to scale and technical efficiency on the companies operating in baking industry was examined. Among others, the results showed that the 3rd generation operational style achieved higher pure technical and overall technical efficiency score than those of 1 st and 2 nd generation.

Regarding the non-listed firms, a study of [29] aimed to determine the efficiency of 16 leading food companies in Indonesia. Both models (CRS and VRS) that were applied, pointed to the relatively high level of achieved efficiency, i.e. $84.9 \%$ and $97.7 \%$, respectively. The results also indicated that inefficient firms needed to optimize the use of labour and raw materials. Contrary to that, instead of focusing on leading firms, some researchers decided to estimate the efficiency of small and medium companies (SMEs). The results of the DEA analysis preformed on the sample of 172 Australian SMEs operating in food, beverages and tobacco industry showed that firms with low union membership as well as family firms were less efficient than other firms. The results also revealed that Australian SMEs could produce the same amount of outputs using about $20 \%$ less inputs [30].

The only paper dealing with the efficiency in the Croatian food industry is the one of [31] in which Croatia is analysed only as a part of Central and East European countries (CEE). Moreover, in that research, only very large companies at CEE level (i.e. 13 countries with total number of 285 firms) were taken into account, solely BCC model was applied and the efficiency was evaluated based on just one input while considering two outputs.

Having in mind all previously stated, the contribution of this paper is as follows. Due to the generally limited number of studies dealing with the firm efficiency in food industry, the paper adds to the scarce literature in this field of research. Moreover, since the analysis is performed on firms operating in Croatia, the paper also adds to the empirical literature of less developed market in general, while at the same time, the paper contributes to the domestic literature in particular since no prior research has estimated overall technical (OTE) and scale efficiency (SE) for the Croatian food industry. Likewise, no prior research has determined returns to scale (RTS) under which Croatian firms operate within food industry. Finally, while focusing solely on large companies, a more homogenous group of firms (dealing with similar competitors, difficulties and industry challenges) is 
formed/analysed and hence more reliable and credible results are obtained.

\section{Methodology and variables}

\subsection{Methodology}

Basic efficiency can be defined as a ratio of output over input. Hence, if a firm wants to improve its efficiency, it has to either: (1) increase the outputs, while keeping the inputs at the same level, (2) decrease the inputs, while keeping the outputs unchanged, or (3) if inputs and outputs increase (decrease) simultaneously, the rate of increase (decrease) for outputs must be greater (lower) than the rate of increase (decrease) for inputs.

Linear programing is a central part of DEA. Main difference between DEA and other methods is that it does not calculate averages, but rather identifies optimal performance. After the seminal work of [32], whose model was named according to their authors - CCR model - and which was based on the assumption of constant returns to scale (CRS), a more generalized DEA model, with the variable returns to scale (VRS) assumption was developed by [33]. Due to its VRS assumption, this model was more flexible and closer to the realworld situations in which changes in all outputs do not always follow a proportional pattern of changes in inputs.

Aside from the type of returns to scale (CRS and VRS), DEA models can be identified based on the model orientation (input and output oriented model). Inputs orientation assumes that firm managers have more control over inputs than over outputs. Hence, if the emphasis (in improving efficiency) is placed on the reduction of inputs, then an input oriented model should be used. Alternatively, if the firm's focus is placed on the maximization of outputs from a given set of inputs, i.e. if managers want to increase firm's efficiency by augmenting their outputs from a given capacity of inputs, then an output oriented model is preferred. Further distinction of the models, as well as the current state of the art in DEA research can be found in [34].

CCR model does not consider scale size of the firm as relevant in assessing overall technical efficiency (OTE). Hence, efficiency scores evaluated from CCR model are OTE and they reflect the ability of the firm to obtain maximum outputs from a given level of inputs. On the other hand, the efficiency scores obtained by BCC model show how efficiently inputs are transformed into outputs given the scale size i.e. BCC model estimates pure technical efficiency (PTE).
Therefore, the firm's scale efficiency (SE) can be calculated by dividing the CCR efficiency scores with BCC efficiency scores. In this way, a decomposition of the overall technical efficiency into pure technical efficiency and scale efficiency can be done.

All efficient DMUs (with efficiency score of 1 or $100 \%$ ) form efficient frontier, while all other nonfrontier firms (with efficiency score less than 1 or $100 \%$ ) are more/less inefficient depending on their distance from the efficient frontier.

In this research, DEA analysis was chosen for several reasons:

- It can deal with multiple inputs and multiple outputs while producing single efficiency score for DMUs.

- Since DEA is a non-parametric technique, no specific functional form has to be determined in advance.

- Overall technical efficiency can be decomposed into pure technical efficiency and scale efficiency.

- Contrary to parametric technique, DEA can be applied to the small sample size [35].

A comprehensive comparison of parametric and nonparametric estimation techniques is provided in [36]. Assumption that scale of economies does not change as size of firms' increase, cannot hold for firms operating in food industry, making a BCC model more appropriate for our investigation than CCR model. Additionally, as output orientation assumes that firms can augment their outputs given their capacity of inputs, in this research an output oriented model is applied. Same return to scale assumption and model orientation can be found in similar studies such as [28], [25], etc.

\subsection{Data and variables}

The dataset used in this study refers to 2018 and is collected from the Amadeus database which contains financial and basic business information about the public and private companies. After omitting all firms for which the data were incomplete or inadequate to be handled with DEA (i.e. firms with missing and/or negative value of chosen inputs/outputs), the final number of large firms amounted 64. As such, the sample captured more than two-thirds $(77.6 \%)$ of operating revenue (turnover), $64.3 \%$ of total employees and $74.3 \%$ of total assets of all firms (regardless of their size) operating in the Croatian food industry and available in Amadeus database. All these elements undoubtedly point to the importance of the large firms in the Croatian food industry. 
According to microeconomic theory, the essential inputs used in the production function are labour, capital and land/materials. Therefore, inputs used in this research, guided by theoretical as well as empirical literature, were presented by the number of employees, firm's total assets and material costs. On the other hand, neo-classical theory of the firm stresses the profit maximisation as the main objective of a business firm. Apart from this, more contemporary managerial theories of the firm suggest that firms might be controlled by its managers instead of its owners, and therefore although still playing an important role, a profit is no longer seen as the sole objective of the firm. In that sense, as another possible aim of the firm, a revenue maximization may occur. Hence, regarding the choice of output variables, two measures were selected, one for each of the previously presented theories, i.e. profit and operating revenue (turnover) of the firm.

Since the choice and the number of inputs and outputs, together with the number of DMUs determine how good discrimination between efficient and inefficient units is, a special attention must be devoted to the number of inputs and outputs in relation to the number of DMUs. As a rule of thumb, the number of DMUs should be at least three times the number of all inputs and outputs taking together [37]. As the number of all inputs and outputs in this analysis was 5 , while the total number of DMUs was 64, it was safe to proceed with the DEA analysis. The analysis was performed with the Performance Improvement Management Software (PIM-DEA).

\section{Results and discussion}

In order to assess and verify the relationship between selected inputs and outputs, a correlation analysis was accomplished. The obtained results are presented in table 1. A positive and statistically significant relationship among all analysed inputs and outputs can be noticed, with correlation coefficients spanning from strong to moderate. The strongest relationship is identified between operating revenue and material costs, as well as between operating revenue and total assets. All coefficients have positive sign, indicating that output increases when input increases, therefore, isotonicity condition related to the data is satisfied [38] confirming that the analysis can be performed with the DEA technique.
Table 1. Correlation analysis

\begin{tabular}{|l|l|l|l|l|l|}
\hline \multirow{2}{*}{} & \multicolumn{5}{|c|}{ Inputs and outputs } \\
\cline { 2 - 6 } & $\begin{array}{c}\text { Total } \\
\text { assets }\end{array}$ & $\begin{array}{c}\text { No. of } \\
\text { employees }\end{array}$ & $\begin{array}{c}\text { Material } \\
\text { costs }\end{array}$ & $\begin{array}{c}\text { Operating } \\
\text { revenue }\end{array}$ & Profit \\
\hline $\begin{array}{l}\text { Total } \\
\text { assets }\end{array}$ & 1 & & & & \\
\hline $\begin{array}{l}\text { No. of } \\
\text { employees }\end{array}$ & $0.676^{* *}$ & 1 & & & \\
\hline $\begin{array}{l}\text { Material } \\
\text { costs }\end{array}$ & $0.874 * *$ & $0.613^{* *}$ & 1 & & \\
\hline $\begin{array}{l}\text { Operating } \\
\text { revenue }\end{array}$ & $0.910^{* *}$ & $0.677^{* *}$ & $0.993^{* *}$ & 1 & \\
\hline Profit & $0.692^{* *}$ & $0.654^{* *}$ & $0.529 * *$ & $0.586^{* *}$ & 1 \\
\hline \multicolumn{5}{|c|}{$* *$. Correlation is significant at the 0.01 level (2-tailed) } \\
& \multicolumn{5}{|c|}{ b. Source: Author's calculations }
\end{tabular}

Descriptive statistics for inputs and outputs of large firms operating in the Croatian food industry is presented in table 2 . The data show variation across the firms. On average, firms have 339 employees, total assets of $€ 32490.25$ and material costs of $€ 31$ 899.77. At the same time, average firm realizes $€ 41$ 636.09 of turnover and $€ 1658.72$ of profits.

Table 2. Descriptive statistics

\begin{tabular}{|l|l|l|l|l|}
\hline \multirow{2}{*}{} & \multicolumn{4}{|c|}{ Inputs and outputs } \\
\cline { 2 - 5 } & Minimum & Maximum & Mean & $\begin{array}{c}\text { Std. } \\
\text { Deviation }\end{array}$ \\
\hline Total assets & 1332.93 & 254358.04 & 32490.25 & 45279.35 \\
\hline $\begin{array}{l}\text { No. of } \\
\text { employees }\end{array}$ & 8 & 1867 & 339.42 & 420.44 \\
\hline $\begin{array}{l}\text { Material } \\
\text { costs }\end{array}$ & 567.06 & 323824.78 & 31899.77 & 49782.86 \\
\hline $\begin{array}{l}\text { Operating } \\
\text { revenue }\end{array}$ & 2484.93 & 387143.99 & 41636.09 & 60435.55 \\
\hline Profit & 8.85 & 11678.68 & 1658.72 & 2540.13 \\
\hline
\end{tabular}

Table 3 brings pure technical efficiency (PTE), overall technical efficiency (OTE), reference set (Ref. set), frequency of the efficient firms in the reference set (Peer count), scale efficiency (SE) and return to scale (RTS) for each DMU covered with the analysis.

The average pure technical efficiency (PTE) of large companies operating in food industry in 2018 was achieved through BCC model and amounted $91.76 \%$, suggesting that these companies can improve their efficiency, or reduce their inefficiency, by augmenting their outputs by $8.24 \%$, given the scale of operation. The obtained results are similar to those of [28], [27] and [29]. Furthermore, since there were 24 firms (37.5\%) that had pure technical efficiency score of $100 \%$, these firms formed efficiency frontier against which all other firms were compared. Remaining 40 firms were inefficient as their scores were less than $100 \%$. 
Table 3. Efficiency scores of large companies in Croatia

\begin{tabular}{|c|c|c|c|c|c|c|}
\hline & \multicolumn{6}{|c|}{ Efficiency } \\
\hline DMU & PTE & OTE & $\begin{array}{l}\text { Ref. set } \\
\text { (DMUs) }\end{array}$ & $\begin{array}{c}\text { Peer } \\
\text { count }\end{array}$ & $S E$ & $R T S$ \\
\hline DMU1 & 100 & 100 & 1 & 17 & 100 & CRS \\
\hline DMU2 & 100 & 100 & 2 & 2 & 100 & CRS \\
\hline DMU3 & 100 & 89.2 & $1,4,49$ & 0 & 89.2 & IRS \\
\hline DMU4 & 100 & 100 & 4 & 16 & 100 & CRS \\
\hline DMU5 & 73.69 & 73.05 & $1,6,10,62$ & 0 & 99.13 & DRS \\
\hline DMU6 & 100 & 100 & 6 & 8 & 100 & CRS \\
\hline DMU7 & 100 & 95.52 & 12,49 & 0 & 95.52 & IRS \\
\hline DMU8 & 94.22 & 94 & $4,6,15,34$ & 0 & 99.77 & IRS \\
\hline DMU9 & 75.19 & 75.16 & $10,38,62$ & 0 & 99.95 & DRS \\
\hline DMU10 & 100 & 100 & 10 & 24 & 100 & CRS \\
\hline DMU11 & 87.23 & 86.56 & $12,49,62$ & 0 & 99.23 & DRS \\
\hline DMU12 & 100 & 100 & 12 & 12 & 100 & CRS \\
\hline DMU13 & 100 & 100 & 13 & 1 & 100 & CRS \\
\hline DMU14 & 93.54 & 92.12 & $\begin{array}{l}1,10,52, \\
62\end{array}$ & 0 & 98.48 & DRS \\
\hline DMU15 & 100 & 100 & 15 & 7 & 100 & CRS \\
\hline DMU16 & 92.96 & 92.05 & $10,38,62$ & 0 & 99.02 & DRS \\
\hline DMU17 & 81.8 & 80.91 & $4,49,62$ & 0 & 98.91 & IRS \\
\hline DMU18 & 81.04 & 74.43 & $49,52,62$ & 0 & 91.85 & DRS \\
\hline DMU19 & 73.19 & 72.29 & 10,62 & 0 & 98.77 & DRS \\
\hline DMU20 & 100 & 95.26 & $12,49,53$ & 0 & 95.26 & DRS \\
\hline DMU21 & 67.93 & 64.96 & $10,38,62$ & 0 & 95.63 & DRS \\
\hline DMU22 & 100 & 72.32 & $\begin{array}{l}1,10,52, \\
62\end{array}$ & 0 & 72.32 & DRS \\
\hline DMU23 & 91.99 & 91.73 & $1,4,10,34$ & 0 & 99.72 & IRS \\
\hline DMU24 & 88.82 & 86.67 & $\begin{array}{l}1,10,52, \\
62\end{array}$ & 0 & 97.58 & IRS \\
\hline DMU25 & 88.96 & 85.04 & $12,49,62$ & 0 & 95.59 & DRS \\
\hline DMU26 & 100 & 98.02 & $2,4,49$ & 0 & 98.02 & IRS \\
\hline DMU27 & 82.4 & 82.37 & $10,38,62$ & 0 & 99.96 & DRS \\
\hline DMU28 & 90.09 & 77.08 & $\begin{array}{l}1,10,52, \\
62\end{array}$ & 0 & 85.55 & DRS \\
\hline DMU29 & 86.86 & 84.94 & $10,38,62$ & 0 & 97.79 & DRS \\
\hline DMU30 & 86.34 & 85.95 & $10,38,62$ & 0 & 99.55 & DRS \\
\hline DMU31 & 100 & 91.58 & $4,6,10,34$ & 0 & 91.58 & DRS \\
\hline DMU32 & 100 & 97.9 & $1,4,15,62$ & 0 & 97.9 & DRS \\
\hline DMU33 & 78.33 & 75.57 & $49,52,62$ & 0 & 96.47 & DRS \\
\hline DMU34 & 100 & 100 & 34 & 9 & 100 & CRS \\
\hline DMU35 & 100 & 98.28 & $1,4,34,52$ & 0 & 98.28 & DRS \\
\hline DMU36 & 94.73 & 93.59 & $1,4,15,62$ & 0 & 98.8 & DRS \\
\hline DMU37 & 93.33 & 93.24 & $4,6,10,34$ & 0 & 99.91 & IRS \\
\hline
\end{tabular}

\begin{tabular}{|c|c|c|c|c|c|c|}
\hline \multirow[b]{2}{*}{$D M U$} & \multicolumn{6}{|c|}{ Efficiency } \\
\hline & PTE & OTE & $\begin{array}{l}\text { Ref. set } \\
\text { (DMUs) }\end{array}$ & $\begin{array}{c}\text { Peer } \\
\text { count }\end{array}$ & $S E$ & $R T S$ \\
\hline DMU38 & 100 & 100 & 38 & 11 & 100 & CRS \\
\hline DMU39 & 91.22 & 90.29 & $1,4,15,62$ & 0 & 98.98 & DRS \\
\hline DMU40 & 97.18 & 96.12 & $1,4,34,52$ & 0 & 98.91 & IRS \\
\hline DMU41 & 95.79 & 93.39 & $4,6,10,34$ & 0 & 97.49 & DRS \\
\hline DMU42 & 93.03 & 92.7 & $\begin{array}{l}10,38,52, \\
62\end{array}$ & 0 & 99.64 & DRS \\
\hline DMU43 & 100 & 82.54 & $\begin{array}{l}1,10,52, \\
62\end{array}$ & 0 & 82.54 & DRS \\
\hline DMU44 & 88.02 & 86.53 & $10,38,62$ & 0 & 98.3 & DRS \\
\hline DMU45 & 87.26 & 86.85 & $\begin{array}{l}1,49,52, \\
62\end{array}$ & 0 & 99.53 & IRS \\
\hline DMU46 & 94.43 & 94.4 & $6,15,34$ & 0 & 99.96 & DRS \\
\hline DMU47 & 91.6 & 91.42 & 12,49 & 0 & 99.8 & IRS \\
\hline DMU48 & 69.52 & 69.51 & $10,38,62$ & 0 & 99.99 & DRS \\
\hline DMU49 & 100 & 100 & 49 & 19 & 100 & CRS \\
\hline DMU50 & 60.95 & 58.75 & 12,62 & 0 & 96.39 & DRS \\
\hline DMU51 & 92.25 & 91.98 & 49,52 & 0 & 99.7 & DRS \\
\hline DMU52 & 100 & 100 & 52 & 16 & 100 & CRS \\
\hline DMU53 & 100 & 100 & 53 & 3 & 100 & CRS \\
\hline DMU54 & 99.22 & 96.64 & 49,53 & 0 & 97.4 & DRS \\
\hline DMU55 & 77.82 & 77.39 & 15,62 & 0 & 99.44 & DRS \\
\hline DMU56 & 91.89 & 91.8 & $\begin{array}{l}4,12,49 \\
62\end{array}$ & 0 & 99.9 & IRS \\
\hline DMU57 & 89.98 & 88.02 & $10,38,62$ & 0 & 97.82 & DRS \\
\hline DMU58 & 93.04 & 92.32 & $\begin{array}{l}1,10,52 \\
62\end{array}$ & 0 & 99.22 & DRS \\
\hline DMU59 & 100 & 93.07 & $12,49,62$ & 0 & 93.07 & DRS \\
\hline DMU60 & 82.48 & 82.4 & $\begin{array}{l}1,10,52, \\
62\end{array}$ & 0 & 99.91 & DRS \\
\hline DMU61 & 79.85 & 79.54 & $4,49,62$ & 0 & 99.61 & IRS \\
\hline DMU62 & 100 & 100 & 62 & 39 & 100 & CRS \\
\hline DMU63 & 98.47 & 94.11 & $12,49,62$ & 0 & 95.57 & DRS \\
\hline DMU64 & 95.93 & 92.86 & $49,52,62$ & 0 & 96.8 & IRS \\
\hline Average & 91.76 & 89.41 & - & - & 97.50 & - \\
\hline
\end{tabular}

Overall technical efficiency scores (OTE) were obtained through the CCR model. Out of 64 food firms, 14 food firms $(21.9 \%)$ were efficient, while remaining food firms were inefficient. Aside from forming efficient frontier, these efficient firms formed "reference set" i.e. they served as an example of the best operating practice that managers of inefficient food firms should follow. The most inefficient food firm, DMU50, had efficiency score of $58.75 \%$ indicating substantial potential for improvement. Among inefficient food firms, almost $40 \%$ of them had overall technical efficiency score that was below the average value of OTE. 
Reference set (Ref. set) contains efficient food firms that serve as benchmarks for each particular inefficient DMU. At the same time, as stated by [39], every efficient food firm is also its own benchmark, e.g. DMU1 for DMU1, DMU2 for DMU2, DMU4 for DMU4 and so on (table 3). However, benchmarks for (inefficient) DMU3 are DMU1, DMU4 and DMU49 (due to space savings, only a number, without DMU notation of efficient food firm is presented in this column i.e. 1, 4 and 49), meaning that in order to become efficient, DMU3 has to use a combination from all three DMUs i.e. DMU1, DMU4 and DMU49 (a virtual food firm).

Peer count shows how frequently each efficient food firm appears as a benchmark for inefficient food firms. Having in mind that every efficient food firm is always its own benchmark, this would mean that e.g. DMU1 is a benchmark for 17 food firms (i.e. itself - as it was previously identified as efficient and therefore its own benchmark (peer); and for additional 16 inefficient food firms), at the same time, DMU2 appears as a benchmark i.e. is referred in the reference set, for 2 food firms (itself and one inefficient food firm i.e. DMU2 and DMU26, respectively). These frequencies can be also used to discriminate among efficient food firms in a way that firm with higher peer count is more likely to be efficient from different aspects and with respect to a large number of factors than firms that appear rarely in the reference set. In that sense, a DMU62 and DMU10 are good example of the best operating practice to be followed.

Scale efficiency (SE) shows that 14 food firms $(21.9 \%)$ had a SE score of $100 \%$, suggesting that the each of them was at the optimal size for its particular input-output mix. Remaining food firms were deemed as scale inefficient. The average value of scale efficiency score was $97.50 \%$ indicating that $2.5 \%$ of inefficiency is generated because of deviation of the existing scale of production from the most productive scale size.

Return to scale (RTS) indicates whether the food firm is experiencing constant (CRS), increasing (IRS) or decreasing (DRS) returns to scale. According to table 3, there were 14 food firms (21.9\%) operating on CRS and 14 food firms (21.9\%) operating on IRS. Most of the food firms, 36 of them $(56.3 \%)$ were operating on DRS, demonstrating over-utilization of the existing scale size. In the latter case, due to the large scale of production and large number of communications levels between firm's management and firm's workforce in production, a managerial efficiency is decreased.
Finally, as our sample consisted of 14 very large and 50 large food firms, we wanted to determine whether there exists any statistically significant difference in efficiency between them. Therefore, we split the sample into two groups according to their size (very large and large) and conducted independent samples t-test (table 4).

Table 4. Independent sample t-test

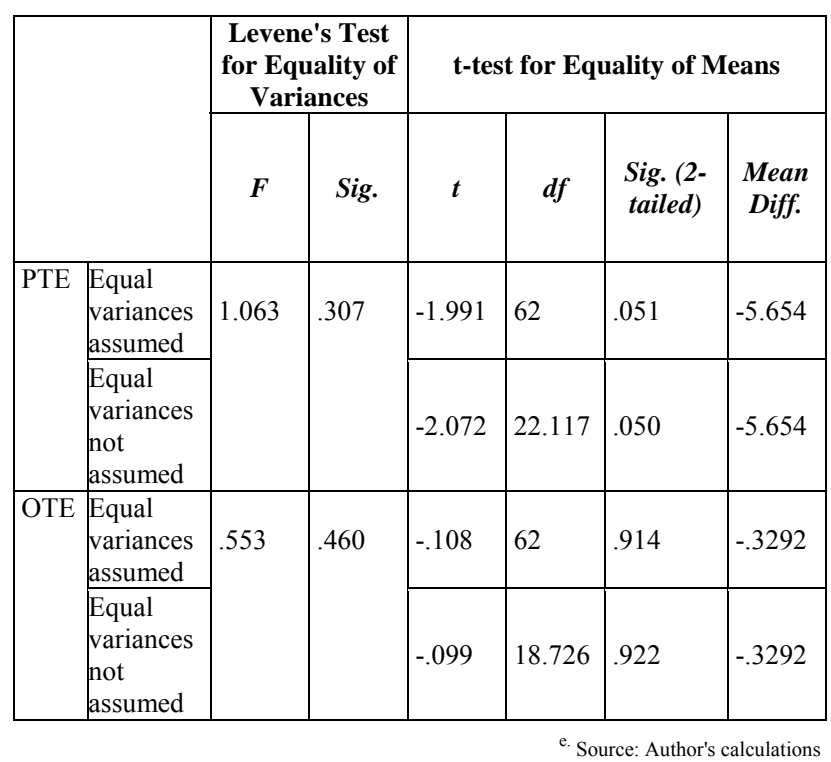

Levene's test was found to be insignificant ( $p>0.01$ ), suggesting that there was no difference between the variance of the very large firms and the variance of the large food firms, regardless of whether the overall technical efficiency or pure technical efficiency was examined. Additionally, the results of the independent samples t-test indicated no statistically significant difference (at the level of 0.01 ) between very large and large firms from the efficiency point of view (no matter whether the OTE or PTE was analysed). Although not found to be statistically significant, the difference in efficiency was more pronounced in PTE.

\section{Conclusion}

The main objective of this research was to assess the efficiency of large firms operating in the Croatian food industry as the one of the most prominent and important segment of the Croatian manufacturing sector. In evaluating efficiency, both, BCC and CCR output oriented models were applied. The obtained results showed that the pure technical efficiency was $91.76 \%$, indicating quite high level of achieved efficiency and suggesting that, on average, Croatian large food firms can augment their outputs by $8.24 \%$, given the scale of operation. As expected, a little lower level of overall technical efficiency is 
recorded in this industry. Still, with the score of $89.41 \%$, this efficiency also proved to be relatively high. Among the all analysed large food firms, DMU62 and DMU10 were detected as good examples of the best operating practice to be followed due to their numerous appearances in reference set. Average score of scale efficiency was $97.50 \%$ suggesting that $2.5 \%$ of inefficiency of food firms occurred due to deviation of their current scale of production from the most productive scale size.

As the most of the food firms, 36 out of 64 $(56.3 \%)$, were operating on decreasing returns to scale (DRS) i.e. were over-utilize the existing scale size, these food firms should downsize their operation in order to increase efficiency.

Finally, the results of the conducted independent sample t-test confirmed that, in terms of efficiency (PTE or OTE), there was no statistically significant difference between large and very large firms operating in the Croatian food industry.

As a suggestion for future research, an efficiency analysis at more aggregated level i.e. manufacturing industry can be performed. In addition, a single analysis (e.g. for Croatia) or a cross-county analysis of manufacturing firm's productivity with the implementation of Malmquist index can be conducted.

\section{References:}

[1] Croatian Financial Agency (FINA), "info.BIZ" - database of Financial Agency. Available at: https://infobiz.fina.hr/Login?ReturnUrl= $\% 2 \mathrm{~F}$ accessed 07.03.2020.

[2] Statista reports, "Food \& Beverages". Available at:

https://www.statista.com/outlook/253/131/food -beverages/croatia\#market-revenue accessed 07.03.2020.

[3] FoodDrink Europe, "Data \& Trends, EU Food and Drink industry, 2019“. Available at: https://www.fooddrinkeurope.eu/publication/da ta-trends-of-the-european-food-and-drinkindustry-2019/ accessed 07.03. 2020.

[4] N. Chiadamrong and P. Sophonsaritsook, "Relationships between supply chain capabilities, competitive advantage and business performance: an exploratory study of the food industry in Thailand," International Journal of Logistics Systems and Management, 20(4), 2015, pp. 477-479.

[5] N. Tsolakis, F. Anastasiadis and J. S. Srai, "Sustainability performance in food supply networks: Insights from the UK industry," Sustainability, 10(9), pp. 3148, 2018.

[6] C. Gaigné, K. Latouche and S. Turolla, "Vertical Ownership and Export Performance: Firm-Level Evidence from the Food Industry," American Journal of Agricultural Economics, 100(1), 2017, pp. 46-72.

[7] C. Bayona-Saez, C. Cruz-Cázares, T. GarcíaMarco and M. Sánchez García, "Open innovation in the food and beverage industry," Management Decision, Vol. 55 No. 3, 2017, pp. 526-546.

[8] Ž. Vaško, A. Ostojić and L. Drinić, "Financial Performance Analysis of the Companies in the Agricultural Sector and Food Industry in the Republic of Srpska," АГРОЗНАЪЕ, 19(2), 2018, pp. 67-78.

[9] M. Pervan, I. Pervan and M. Ćurak, "The influence of age on firm performance: evidence from the Croatian food industry," Journal of Eastern Europe Research in Business and Economics, 2017(1), pp. 1-10.

[10] G. Buturac, Ž. Lovrinčević and D. Mikulić, "International competitiveness and restructuring of the Croatian food industry," Acta Oeconomica, 67(3), 2017, pp. 435-462.

[11] A. Emrouznejad and G.Yang, "A survey and analysis of the first 40 years of scholarly literature in DEA: 1978-2016," SocioEconomic Planning Sciences, vol. 61, 2018, pp. 4-8.

[12] J.S. Liu, L.Y.Y. Lu, W.M. Lu, B. J.Y. Lin, “A survey of DEA applications," Omega, vol 41, issue 5, 2013, pp. 893-902.

[13] S. Razipour-Ghaleh Jough, F. H. Lotfi, G. Jahanshahloo, M. Rostamy-malkhalifeh and $\mathrm{H}$. Sharafi, "Finding closest target for bank branches in the presence of weight restrictions using data envelopment analysis," Annals of Operations Research, 2019, pp. 1-33.

[14] D. Adeabah, A. Gyeke-Dako and C. Andoh, "Board gender diversity, corporate governance and bank efficiency in Ghana: a two stage data envelope analysis (DEA) approach," Corporate Governance, 19 (2), 2019, pp. 299-320.

[15] A. A. Shah, D. Wu and V. Korotkov, "A data envelopment analysis and the Malmquist productivity index analysis," Sustainability, 11(8), 2019, pp. 2398.

[16] M. Barat, G. Tohidi, M. Sanei, and S. Razavyan, "Data envelopment analysis for decision making unit with nonhomogeneous internal structures: An application to the 
banking industry," Journal of the Operational Research Society, 70(5), 2019, pp. 760-769.

[17] S. Kohl, J. Schoenfelder, A. Fügener and J. O. Brunner, "The use of Data Envelopment Analysis (DEA) in healthcare with a focus on hospitals," Health care management science, 22(2), 2019, pp. 245-286.

[18] B. Şahin and G. İlgün, "Assessment of the impact of public hospital associations (PHAs) on the efficiency of hospitals under the ministry of health in Turkey with data envelopment analysis," Health care management science, 22(3), 2019, pp. 437-446.

[19] A. Chitnis and D. K. Mishra, "Performance Efficiency of Indian Private Hospitals Using Data Envelopment Analysis and Superefficiency DEA," Journal of Health Management, 21(2), 2019, pp. 279-293.

[20] C. Yildirim, H. Kacak, S. Yildirim and S. Kavuncubasi, "Comprehensive Efficiency Assessment of Turkish Teaching Hospitals: Technical, Pure Technical and Scale Efficiencies with Data Envelopment Analysis," Journal of Applied Business and Economics, 21(3), 2019, pp. 124-140.

[21] M. Torres-Samuel, C. Vásquez, A. Viloria, T. C. Borrero, N. Varela, D. Cabrera, ... and J. P. Lis-Gutiérrez, "Efficiency analysis of the visibility of Latin American universities and their impact on the ranking web," In International Conference on Data Mining and Big Data, 2018, pp. 235-243.

[22] G. L. Yang, H. Fukuyama and Y. Y. Song, "Measuring the inefficiency of Chinese research universities based on a two-stage network DEA model," Journal of Informetrics, 12(1), 2018, pp. 10-30.

[23] M. Gnewuch and K. Wohlrabe, "Superefficiency of education institutions: an application to economics departments," Education Economics, 26(6), 2018, pp. 610623.

[24] J. P. Guironnet and N. Peypoch, "The geographical efficiency of education and research: The ranking of US universities," Socio-Economic Planning Sciences, 62, 2018, pp. 44-55.

[25] M. Afzal and M. Ayaz, "Efficiency of food sector of Pakistan - a DEA analysis," Asian Journal of Empirical Research, vol. 3:10, 2013, pp. 1310-1330.

[26] A. Tektas and E.O. Tosun, "Performance Benchmarking in Turkish Food and Beverage Industry," Communications of the IBIMA, vol. 2010, pp. 1-10.
[27] J.L. Hu, C.N. Chiu, H.T. Chu, "Managerial Efficiency in the Food and Beverage Industry in Taiwan," Journal of Hospitality Financial Management, vol. 27, Iss. 1, 2019, pp. 39-48.

[28] C.W. Chang, K.S. Wu, B.G. Chang, and K.R. Lou, "Measuring Technical Efficiency and Returns to Scale in Taiwan's Baking Industry-A Case Study of the $85^{\circ} \mathrm{C}$ Company," Sustainability, 11, 2019, pp. 1-14.

[29] A. Machmud, E. Ahman, P. D. Dirgantari, I. Waspada and A.B.D. Nandiyanto, "Data envelopment analysis: The efficiency study of food industry in Indonesia," Journal of Engineering Science and Technology, vol. 14, no. 1, 2019, pp. $479-488$.

[30] B. Kotey and C. J. O’Donnell, "Data Envelopment Analysis in Small and Medium Enterprises: A Study of the Australian Food, Beverages and Tobacco Manufacturing Industry," Small Enterprise Research, vol. 10:2, 2002, pp. 1-22.

[31] Z. Lukac and M. Gardijan, "Measuring the efficiency of the food industry in Central and East European countries by using the Data Envelopment Analysis approach “, Proceedings of the 6th International conference on operations research and enterprise systems (ICORES 2017), 2017, pp. 385-392.

[32] A. Charnes, W.W. Cooper and E. Rhodes, "Measuring the efficiency of decision making units," European Journal of Operations Research, vol. 2 no. 6, 1978, pp. 429-441.

[33] R.D. Banker, A. Charnes, and W.W. Cooper, "Some models for the estimation of technical and scale inefficiencies in data envelopment analysis," Management Science, vol. 30, no. 9, 1984, pp. 1078-1092.

[34] J. Zhu, Data envelopment analysis: A handbook of empirical studies and applications. International Series in Operations Research \& management science. (vol. 238). Springer, 2016.

[35] Q. Iqbal and H. M. Awan, "Technical, pure technical and scale efficiency analysis of insurance companies of Pakistan," International Journal of Business and Management Review, vol. 3, no. 4, 2015, pp. 82-92.

[36] B.J. Parman and A. M. Featherstone, "A comparison of parametric and nonparametric estimation methods for cost frontiers and economic measures," Journal of Applied Economics, vol. 22:1, 2019, pp. 60-85.

[37] W.F. Bowlin, "Measuring Performance: An Introduction to Data Envelopment Analysis 
(DEA)," The Journal of Cost Analysis, vol. 15:2, 1998, pp. 3-27.

[38] C.N. Wang, N.T. Nguyen and T.T. Tran, "Integrated DEA Models and Grey System Theory to Evaluate Past-to-Future Performance: A Case of Indian Electricity Industry," Sci. World J. 2015, pp. 1-17.

[39] A. O. Yasar, Health care benchmarking and performance evaluation: An assessment using Data envelopment analysis, Springer, 2016. 